\title{
Tillage and Nitrogen Source Impacts on Relationships between Nitrous Oxide Emission and Nitrogen Recovery Efficiency in Corn
}

\author{
Rex A. Omonode and Tony J. Vyn*
}

\begin{abstract}
Quantitative understanding of relationships between $\mathrm{N}_{2} \mathrm{O}$ emission and plant $\mathrm{N}$ uptake are needed to select environmentally optimal management systems for corn (Zea mays L.) production. Studies were conducted from 2014 to 2016 in Indiana to assess long-term tillage and $\mathrm{N}$ source effects on $\mathrm{N}_{2} \mathrm{O}$ emission, and in 2015 and 2016 on relationships between $\mathrm{N}_{2} \mathrm{O}$ losses and $\mathrm{N}$ recovery efficiency (NRE) and $\mathrm{N}$ use efficiency (NUE), in a continuous corn system. Tillage treatments (mostly in place since 1975) consisted of no till (NT), strip till (ST), chisel plow (CP), and moldboard plow (MP), whereas the $\mathrm{N}$ source comparison involved sidedress urea ammonium nitrate applied at $220 \mathrm{~kg} \mathrm{~N} \mathrm{ha}^{-1}$ with and without nitrapyrin. Grain yield averaged $6.5 \%$ greater for MP than for CP and NT in the 3-yr period. Nitrapyrin never increased grain yield or NRE but reduced cumulative seasonal $\mathrm{N}_{2} \mathrm{O}$ emission in $1 \mathrm{yr}$. Tillage affected $\mathrm{N}_{2} \mathrm{O}$ emission in 2 of $3 \mathrm{yr}$, when emissions decreased in the order MP > CP > ST > NT. Significant negative linear relationships existed between $\mathrm{N}_{2} \mathrm{O}$ emission and $\mathrm{NRE}$ under NT and ST, and between $\mathrm{N}_{2} \mathrm{O}$ and NUE under ST, but not for CP and MP. Overall, $\mathrm{N}_{2} \mathrm{O}$ losses under ST and NT decreased by 17 and $13 \mathrm{~g} \mathrm{~N} \mathrm{ha}^{-1}$, respectively, per unit increase of NRE, and by $63 \mathrm{~g} \mathrm{~N}$ $\mathrm{ha}^{-1}$ per unit increase of NUE under ST. Our results confirmed that selected management systems such as NT or ST that improved NRE and/or NUE can potentially reduce $\mathrm{N}_{2} \mathrm{O}$ emissions during continuous corn production.
\end{abstract}

\section{Core Ideas}

- Seasonal $\mathrm{N}_{2} \mathrm{O}$ losses were lower for no till (NT) and strip till (ST) vs. chisel and moldboard plow.

- Mean N recovery efficiency (NRE) in continuous corn with $220 \mathrm{~kg}$ $\mathrm{N} \mathrm{ha}^{-1}$ exceeded $70 \%$.

- Negative linear relationships existed between NRE or NUE and $\mathrm{N}_{2} \mathrm{O}$ under NT and ST.

- Rate of cumulative $\mathrm{N}_{2} \mathrm{O}$ emission decline per unit gain in NRE was highest under NT.
$\mathrm{N}$ ITROUS OXIDE is both an important ozonedepleting chemical (Ravishankara et al., 2009) and a major greenhouse gas believed to contribute to global climate change with a potency that is about 265 times the global warming potential of $\mathrm{CO}_{2}$, over a 100 -yr timescale (Myhre et al., 2013; IPCC, 2014). In agricultural soils, $\mathrm{N}_{2} \mathrm{O}$ is produced predominantly through bacterial-mediated transformations of inorganic N (Bremner and Blackmer, 1978; Klemedtsson et al., 1988; Bremner, 1997). However, the quantity of inorganic $\mathrm{N}$ available for transformation is determined by the balance between the amount of $\mathrm{N}$ applied and the amount taken up by crop plants, after a complex interaction among $\mathrm{N}$ management, tillage, and rotation practices, and dominant environmental factors (Venterea et al., 2012). Therefore, the common assumption among scientists is that adoption of management practices that increased $\mathrm{N}$ uptake, $\mathrm{N}$ recovery efficiency (NRE) and/or $\mathrm{N}$ use efficiency (NUE) will reduce $\mathrm{N}_{2} \mathrm{O}$ emission during crop production.

In the Corn Belt and elsewhere in the United States, where corn (Zea mays L.) production consumed $\sim 6.3 \mathrm{Tg}$ or $47 \%$ of the 13.3 Tg of the $\mathrm{N}$ fertilizers in 2014 (USDA-ERS, 2018), the consequences of individual $\mathrm{N}$ management options such as rate (Breitenbeck and Bremner, 1986a; McSwiney and Robertson, 2005; Halvorson and Bartolo 2014; Venterea et al., 2016), source (Breitenbeck and Bremner, 1986b; Liu et al., 2007; Halvorson et al., 2010a, 2011; Venterea et al., 2010, 2011; Halvorson and Del Grosso, 2012; Omonode and Vyn. 2013), timing (Liu et al., 2005; Engel et al., 2010; Drury et al., 2012; Burzaco et al., 2013; Venterea and Coulter, 2015), and placement (Liu et al., 2006; Fujinuma et al., 2011; Halvorson and Del Grosso, 2013) on $\mathrm{N}_{2} \mathrm{O}$ emission have been well documented. Tillage system effects on $\mathrm{N}_{2} \mathrm{O}$ emissions have also been reported (Liu et al., 2005; Halvorson et al., 2008, 2010b; Omonode et al., 2011), albeit with inconsistencies attributed to contrasting tillage effects on soil biophysical properties (van Kessel et al., 2013). Similarly, effects of tillage (Al-Kaisi and Kwaw-Mensah, 2007), N management options (Cassman et al., 2002; Randall et al., 2003; Randall and Vetsch, 2005; Ciampitti and Vyn, 2011; Burzaco et al., 2014; Wang et al., 2014; Rubin et al., 2016), and crop residue

Dep. of Agronomy, Purdue Univ., Lilly Hall of Life Sciences, 915 W. State St., West Lafayette, IN 47907. Assigned to Associate Editor Martin Burger.

Abbreviations: CP, chisel plow; DAP, days after application; FIEF, fertilizer-induced emission factor; GNU, grain nitrogen uptake; GY, grain yield; MP, moldboard plow; NRE, nitrogen recovery efficiency; NT, no till; NUE, nitrogen use efficiency; ST, strip till; TNU, total aboveground nitrogen uptake; $\mathrm{N}_{2} \mathrm{O}_{G Y^{\prime}}$ yield-scaled nitrous oxide; $\Sigma_{G S} \mathrm{~N}_{2} \mathrm{O}$, cumulative seasonal nitrous oxide; UAN, urea ammonium nitrate; VWC, volumetric water content. 
removal (Sawyer et al., 2017) on NRE and NUE in corn production have been fairly well documented. However, most of these authors showed that, on average, corn NRE seldom exceeded $50 \%$ when $\mathrm{N}$ fertilizer rates were close to their agronomic optimums, regardless of management intensity and agroecology. Thus, in theory, much of the $\mathrm{N}$ applied during crop production is either lost through leaching or made available for bacterial denitrification, whereby some is subsequently emitted as $\mathrm{N}_{2} \mathrm{O}$.

Although many studies in the United States have assessed the effects of $\mathrm{N}$ management options on a corn crop's NUE and NRE, or separately assessed management consequences for $\mathrm{N}_{2} \mathrm{O}$ emissions, little research has been conducted that simultaneously evaluated management effects on corn NRE and $\mathrm{N}_{2} \mathrm{O}$ emissions (Omonode et al., 2017; Venterea et al., 2016), and even less research has assessed the relationships between $\mathrm{N}_{2} \mathrm{O}$ emission and $\mathrm{N}$ uptake and/or NUE (Omonode et al., 2017). In their recent study involving data collected across $\mathrm{N}$ management systems for corn in North America, Omonode et al. (2017) found a significant negative relationship between $\mathrm{N}_{2} \mathrm{O}$ loss and $\mathrm{NRE}$, especially in the context of $\mathrm{N}$ rate and timing management variables. However, the analysis by these authors did not include the influence of tillage or nitrification inhibitor application on these relationships. To the best of our knowledge, no research has been conducted to quantify the relationship of $\mathrm{N}_{2} \mathrm{O}$ with corn $\mathrm{N}$ uptake and use efficiencies in long-term tillage systems. The objectives of this study were to assess the effects of long-term tillage and $\mathrm{N}$ application with and without nitrification inhibitor on (i) seasonal $\mathrm{N}_{2} \mathrm{O}$ emissions, (ii) corn $\mathrm{N}$ use efficiencies, and (iii) the relationships between seasonal $\mathrm{N}_{2} \mathrm{O}$ loss and $\mathrm{N}$ use efficiencies in rainfed corn.

\section{Materials and Methods}

\section{Site Description and Experimental Design}

The study was conducted in long-term tillage plots established in 1975 at the Purdue University Agronomy Center for Research and Education near West Lafayette, IN. The tillage treatments consisted of no till (NT), moldboard (MP), chisel plow (CP), and strip till (ST) applied to continuous corn; individual tillage plots measured $\sim 46 \mathrm{~m}$ long and $10 \mathrm{~m}$ wide. The ST treatment was established in 2009 after conversion from ridge tillage that was applied from 1975 to 2008. For this study, the experimental layout was a split-plot design where tillage was the main plot, and the subplot was $\mathrm{N}$ source, which consisted of urea ammonium nitrate (UAN) with and without a nitrification inhibitor (nitrapyrin).

Corn was planted in 76-cm rows with a John Deere 1780 six-row planter on 24 Apr. 2014 (Pioneer P1221AMX; HXX, LL, RR2), 23 May 2015 (Pioneer P1360CHR), and $20 \mathrm{Apr}$. 2016 (Pioneer P1360CHR) with starter N applied at $26 \mathrm{~kg}$ $\mathrm{N} \mathrm{ha}^{-1}$ as ammonium polyphosphate $(10-34-0 \mathrm{~N}-\mathrm{P}-\mathrm{K})$ in all $3 \mathrm{yr}$. In 2014, the tillage plots were divided into two halves (subplots, 46-m lengths of six corn rows) at the $\mathrm{V} 4$ corn growth stage (Abendroth et al., 2011), and UAN alone was applied at the rate of $220 \mathrm{~kg} \mathrm{~N} \mathrm{ha}^{-1}$ to one half, and the other half received the same amount of $\mathrm{N}$ plus nitrapyrin (UAN+nitrapyrin). In 2015 and 2016, the UAN and UAN+nitrapyrin treatments were applied as occurred in 2014, but only to two-thirds of the subplot lengths, whereas the other one-third received zero $\mathrm{N}$ without nitrapyrin and acted as control plots to enable estimation of yield-scaled $\mathrm{N}_{2} \mathrm{O}, \mathrm{NRE}$, and NUE. For this location and soil type, Burzaco et al. $(2013,2014)$ showed that corn yield and $\mathrm{N}_{2} \mathrm{O}$ emission were similar with and without nitrapyrin application when no $\mathrm{N}$ was applied.

The UAN was sidedressed by coulter injection $(\sim 10 \mathrm{~cm}$ deep into the soil) on 22 May 2014, 11 June 2015, and 20 May 2016 using a seven-knife DMI NutriPlacer 2800 liquid N applicator equipped with one coulter per knife. The nitrapyrin source was Instinct 2 (Dow Agrosciences), a recent commercially available, reformulated water-soluble nitrapyrin especially designed for application with liquid $\mathrm{N}$ sources. Nitrapyrin was applied by pumping it from a companion tank into the UAN fertilizer line at the recommended rate of $2.6 \mathrm{~kg} \mathrm{ha}^{-1}\left(\sim 0.44 \mathrm{~kg}\right.$ a.i. ha $\left.{ }^{-1}\right)$. All treatments were replicated three times, and other agronomic practices including application of lime, $\mathrm{P}$, and $\mathrm{K}$ were performed consistent with practices in the last $40 \mathrm{yr}$.

\section{Nitrous Oxide Emission Measurement}

Daily fluxes of $\mathrm{N}_{2} \mathrm{O}$ were measured from 23 May to 20 Aug. 2014, 16 June to 2 Sept. 2015, and from 23 May to 2 Sept. 2016 for a total of 19, 14, and 21 measurement days, respectively. Flux measurements commenced $\leq 3 \mathrm{~d}$ after UAN application, and gas samples were collected twice weekly for 6 to $8 \mathrm{wk}$, and weekly thereafter for the rest of the growing season, using static vented chambers (Mosier et al., 2006). On each sampling date, gas samples were collected from the chamber headspace through a rubber septum at $0-, 10-, 20-$, and 30 -min intervals after chamber deployment using a gas-tight syringe, and then $25 \mathrm{~mL}$ of the sampled gas was transferred into preevacuated 12-mL Exetainer vials (Labco). All gas sampling activities occurred between 1200 and $1500 \mathrm{~h}$ of each sampling date, when biological activity and flux rates were considered to represent the daily average emission for Indiana (Omonode and Vyn, unpublished data, 2015). Gas samples were immediately transported to the laboratory, where $\mathrm{N}_{2} \mathrm{O}$ concentrations in the samples were determined on a gas chromatograph equipped with an automatic Combi-Pal injection system, using a 3.05m-long Porapak Q with $\operatorname{Ar}(95 \%)$ carrier gas with an electron capture detector set at $350^{\circ} \mathrm{C}$ (Varian $3800 \mathrm{GC}$ ).

Flux rates of $\mathrm{N}_{2} \mathrm{O}$ were calculated by linear regression of $\mathrm{N}_{2} \mathrm{O}$ concentration versus time since closure of the chamber top. The $\mathrm{N}_{2} \mathrm{O}$ flux measured by the static chambers was calculated using the rate of change in the $\mathrm{N}_{2} \mathrm{O}$ concentration $\left(\partial_{\mathrm{c}} / \partial_{\mathrm{t}}\right.$ mol $\mathrm{min}^{-1}$ ) inside the chamber during a 30-min cover deployment expressed as

$$
F_{\mathrm{N}_{2} \mathrm{O}}=\left(\frac{\partial_{\mathrm{c}}}{\partial_{\mathrm{t}}}\right)\left(\frac{M}{V_{\mathrm{m}}}\right)\left(\frac{V}{A}\right)
$$

where $\partial_{c}$ is the change of $\mathrm{N}_{2} \mathrm{O}$ concentration in the chamber headspace during an enclosure period $\left(\mu \mathrm{L} \mathrm{L}^{-1}\right), \partial_{\tau}$ is the enclosure period (h), $M$ is the molar mass of $\mathrm{N}$ in $\mathrm{N}_{2} \mathrm{O}\left(\mathrm{g} \mathrm{mol}^{-1}\right), V_{\mathrm{m}}$ is the molar volume of gas at the sampling temperature and atmospheric pressure $\left(\mathrm{L} \mathrm{mol}^{-1}\right), V$ is the headspace volume $\left(\mathrm{m}^{3}\right)$, and $A$ is the area covered $\left(\mathrm{m}^{2}\right) ;(V / A)$ is the chamber headspace height.

Cumulative $\mathrm{N}_{2} \mathrm{O}$ emissions during the measurement periods were calculated by linearly interpolating $F_{\mathrm{N} 2 \mathrm{O}}$ between sampling 
dates, and cumulative seasonal emission $\left(\Sigma_{\mathrm{GS}} \mathrm{N}_{2} \mathrm{O}\right)$ was estimated as the sum of all sampling dates.

\section{Grain Yield, Nitrogen Uptake, and Use Efficiency Parameters}

At physiological maturity, corn $\mathrm{N}$ uptake was determined by sampling the total plant aboveground biomass (plant biomass). Plant biomass was measured from 10 consecutive corn plants in the third or fourth row. The plants were manually cut $<5 \mathrm{~cm}$ above the soil surface and separated into ears and stover, ears were air dried and shelled, all aboveground plant components (grains, stover, and cobs) were further dried at $65^{\circ} \mathrm{C}$ to a constant weight, and plant biomass yield was recorded. Subsamples were taken, ground, and analyzed for $\mathrm{N}$ concentration with an elemental analyzer (VarioMax, Elementar) in a commercial laboratory (A\&L Great Lakes Laboratories, Fort Wayne, IN). Total plant $\mathrm{N}$ uptake (TNU) on a kilogram-per-hectare basis was calculated as the product of the grain, stover, plus cob dry matters and their $\mathrm{N}$ respective concentrations in each plot. Thereafter, corn in the center two rows of each six-row plot was machine harvested, its grain was weighed, and its moisture content was determined, and final grain yields (GY) were adjusted to $155 \mathrm{~g}$ $\mathrm{kg}^{-1}$ moisture content.

Nitrogen use efficiency in terms of GY (NUE) and the amount of applied $\mathrm{N}$ recovered by the corn plants (NRE) were calculated as

$$
\begin{aligned}
& \operatorname{NUE}\left(\mathrm{kg} \mathrm{kg}^{-1}\right)=\frac{\mathrm{GY}_{\mathrm{N}}-\mathrm{GY}_{0}}{\Delta \mathrm{N}_{\text {applied }}} \\
& \operatorname{NRE}(\%)=\left(\frac{\mathrm{TNU}_{\mathrm{N}}-\mathrm{TNU}_{0}}{\Delta \mathrm{N}_{\text {applied }}}\right) 100
\end{aligned}
$$

where $\mathrm{GY}_{\mathrm{N}}$ and $\mathrm{GY}_{0}$ are GY for fertilized and unfertilized plots respectively, TNU is total (grain + stover + cob) $\mathrm{N}$ uptake with $\mathrm{TNU}_{\mathrm{N}}$ being the TNU of $\mathrm{N}$-fertilized plots and $\mathrm{TNU}_{0}$ being the TNU of unfertilized plots, and $\Delta \mathrm{N}_{\text {applied }}$ is the differential of $\mathrm{N}$ fertilizer applied.

\section{Data Analysis and Statistical Procedures}

Treatment effects on GY and N uptake and use efficiency parameters were assessed using the PROC GLM procedure where tillage and $\mathrm{N}$ source were considered fixed, and block (or replicate), year, and their interactions constituted random effects. The normality of $\mathrm{N}_{2} \mathrm{O}$ data distribution was assessed using the PROC UNIVARIATE procedure, and the data was natural $\log$ transformed when necessary before they were used in further analysis. Treatment effects on daily $\mathrm{N}_{2} \mathrm{O}$ emissions were assessed using the analysis of repeated measurement in the PROC MIXED procedure where tillage, $\mathrm{N}$ source, measurement dates, and their interactions were considered fixed effects, blocks and tillage $\times \mathrm{N}$ source interaction constituted random effects, and the repeated option was $\mathrm{N}$ source nested in tillage. Thereafter, the data were pooled and analyzed, with the year of measurement as an additional random effect.

Fertilizer-induced $\mathrm{N}_{2} \mathrm{O}$ emission factor (FIEF) for the treatments was calculated by subtracting the cumulative seasonal $\mathrm{N}_{2} \mathrm{O}$ for the unfertilized control $\left(\Sigma_{\text {control }} \mathrm{N}_{2} \mathrm{O}\right)$ from the $\Sigma_{\mathrm{GS}} \mathrm{N}_{2} \mathrm{O}$ of the treatment plots and dividing by the amount of $\mathrm{N}$ applied. Yield-scaled $\mathrm{N}_{2} \mathrm{O}\left(\mathrm{N}_{2} \mathrm{O}_{\mathrm{Gr}}\right.$ amount of $\mathrm{N}$ emitted as $\mathrm{N}_{2} \mathrm{O}$ per unit of GY) was estimated by dividing $\Sigma_{\mathrm{GS}} \mathrm{N}_{2} \mathrm{O}$ by GY. Treatment effects on $\Sigma_{G S} \mathrm{~N}_{2} \mathrm{O}$, FIEF, and $\mathrm{N}_{2} \mathrm{O}_{\mathrm{GY}}$ were assessed using the PROC GLM procedure; tillage and $\mathrm{N}$ source were fixed factors, and block replicate, year, and their interactions were considered random effects. The treatment effect was declared significant at $P \leq 0.05$, and means were separated using the PDIFF option in the LSMEANS statement of PROC GLM when the effect was significant.

The relationships between $\mathrm{N}_{2} \mathrm{O}$ and TNU, NUE, and NRE within tillage and $\mathrm{N}$ source were assessed using single-factor regression models where $\mathrm{N}_{2} \mathrm{O}$ was considered the response variable, and $\mathrm{N}$ uptake, NUE, and NRE were the independent variables. The strengths of the relationships were assessed by the values of the regression $r^{2}$, and the relationship was considered significant at $P=0.05$. When regression models were significant, equality of model coefficients across treatments were tested using Proc GLM/SOLUTION, and the CONTRAST "test equal slopes" statement. Regression slopes were considered equal at the $P \leq 0.05$ level. All analyses were performed using the SAS 9.3 package (SAS Institute, 2013).

\section{Results}

\section{Grain Yield, Nitrogen Uptake, and Use Efficiency}

Grain yield was significantly affected by tillage $(P=0.003)$ and $\mathrm{N}$ source in $2014(P=0.008)$, but neither tillage nor $\mathrm{N}$ source affected GY in 2015 and 2016. Similarly, yield was not affected by tillage $\times \mathrm{N}$ source interactions in any year (Supplemental Table S1). Treatment effects on TNU and grain $\mathrm{N}$ uptake (GNU), NUE, and NRE in 2015 and 2016 are presented in Table 1.

In 2015, TNU, GNU, and NRE were affected by both tillage and $\mathrm{N}$ source, but not by the tillage $\times \mathrm{N}$ source interaction. Total N uptake for 2015 was similar for NT and ST and was much lower for MP and CP. Similarly, NRE for 2015 was greater for NT and ST (average $=57 \%$ ) versus CP (45\%), and NRE was $10 \%$ greater for UAN alone than for UAN+nitrapyrin. Neither tillage nor N source affected NUE in 2015. In 2016, N uptake and NRE were not affected by tillage, $\mathrm{N}$ source, and the tillage $\times \mathrm{N}$ source interaction (Table 1). Averaged across treatments, TNU, GNU, and NRE were significantly higher in 2016 than in 2015. Across years, NUE averaged $37 \mathrm{~kg} \mathrm{~kg}^{-1}$, and NRE averaged $72 \%$ across tillage and $\mathrm{N}$ sources (Supplemental Table S2).

\section{Nitrous 0xide Emission}

Daily $\mathrm{N}_{2} \mathrm{O}$ emission was affected by tillage and tillage $\times \mathrm{N}$ source interaction in 2014, and by tillage, $\mathrm{N}$ source, and their interaction in 2016. Neither tillage, $\mathrm{N}$ source, nor tillage $\times \mathrm{N}$ source affected $\mathrm{N}_{2} \mathrm{O}$ emissions in 2015 (Table 2). In 2014, $\mathrm{N}_{2} \mathrm{O}$ emission was relatively low between 23 May and 3 June $(11 \mathrm{~d}$ after application $[\mathrm{DAP}])$, increased rapidly from a prior average of 41 to $69 \mathrm{~g} \mathrm{~N} \mathrm{ha}^{-1}$ on 10 June (19 DAP), then declined rapidly to $\sim 40 \mathrm{~g} \mathrm{~N} \mathrm{ha}^{-1}$ on 17 June, except for MP where emission remained high and averaged $70 \mathrm{~g} \mathrm{~N} \mathrm{ha}^{-1}$ (Fig. 1a). During this period, $\mathrm{N}_{2} \mathrm{O}$ emission was significantly greater for MP relative to $\mathrm{CP}$ and $\mathrm{ST}$, which were in turn greater than NT, and for UAN compared with UAN+nitrapyrin (Fig. 1b). Thereafter, emission increased rapidly again across treatments to peak at $\sim 64 \mathrm{~g} \mathrm{~N} \mathrm{ha}^{-1}$ on 24 June (34 DAP); these emissions remained 
high until 1 July, then declined rapidly to near baseline on 11 July (51 DAP) and remained low for the rest of the growing season. On average, daily $\mathrm{N}_{2} \mathrm{O}$ was greatest for $\mathrm{MP}\left(47.1 \mathrm{~g} \mathrm{~N} \mathrm{ha}^{-1} \mathrm{~d}^{-1}\right)$ and smallest for $\mathrm{NT}^{2}\left(38 \mathrm{~g} \mathrm{~N} \mathrm{ha}^{-1} \mathrm{~d}^{-1}\right)$, and $\mathrm{N}_{2} \mathrm{O}$ intensity was in the order MP $>\mathrm{ST}=\mathrm{CP}=\mathrm{NT}$ but was identical for UAN and UAN+nitrapyrin (Table 2).

Similar to the pattern observed for 2014, relatively small but distinct emission peaks occurred on 23 June 2015 (12 DAP), when average $\mathrm{N}_{2} \mathrm{O}$ increased from 47 to $58 \mathrm{~g} \mathrm{~N} \mathrm{ha}^{-1} \mathrm{~d}^{-1}$, and again from $31 \mathrm{~g} \mathrm{~N} \mathrm{ha}^{-1}$ on 15 July to $50 \mathrm{~g} \mathrm{~N} \mathrm{ha}^{-1} \mathrm{~d}^{-1}$ on 21 July (40 DAP), followed by relatively high $\mathrm{N}_{2} \mathrm{O}$ loss in the next $7 \mathrm{~d}$ before declining rapidly to baseline by 14 August (Fig. 1c and 1d). In contrast, the daily $\mathrm{N}_{2} \mathrm{O}$ emission pattern for 2016 was such that one prominent $\mathrm{N}_{2} \mathrm{O}$ emission peak was observed on 2 June (12 DAP) when $\mathrm{N}_{2} \mathrm{O}$ increased dramatically from $37 \mathrm{~g} \mathrm{~N} \mathrm{ha}^{-1} \mathrm{~d}^{-1}$ starting on 23 May to peak at $72 \mathrm{~g} \mathrm{~N}^{-1} \mathrm{~d}^{-1}$, averaged across tillage systems (Fig. 1e), and then declined as dramatically to $\sim 15 \mathrm{~g} \mathrm{~N} \mathrm{ha}^{-1}$ on 20 June (from 46 to $105 \mathrm{~kg} \mathrm{~N} \mathrm{ha}^{-1} \mathrm{~d}^{-1}$ across $\mathrm{N}$ sources, Fig. 1f). However, much smaller but equally significant emission peaks also occurred on 24 June (24 DAP) when $\mathrm{N}_{2} \mathrm{O}$ increased from $\sim 10 \mathrm{~g}$ $\mathrm{N} \mathrm{ha}^{-1} \mathrm{~d}^{-1}$ on 20 June to $\sim 40 \mathrm{~g} \mathrm{Nha}^{-1}$, and on 21 July when $\mathrm{N}_{2} \mathrm{O}$ peaked at $25 \mathrm{~g} \mathrm{~N} \mathrm{ha}^{-1} \mathrm{~d}^{-}$for CP and MP (51 DAP) and thereafter

Table 1. Generalized linear model showing probability of significant tillage and N source effects on mean total (TNU) and grain N uptake (GNU) and N use (NUE) and recovery efficiency (NRE) in 2015 and 2016 cropping seasons near West Lafayette, IN.

\begin{tabular}{|c|c|c|c|c|c|c|c|c|}
\hline \multirow{2}{*}{ Tillage or $\mathrm{N}$ source } & \multicolumn{4}{|c|}{2015} & \multicolumn{4}{|c|}{2016} \\
\hline & TNU & GNU & NUE & NRE & TNU & GNU & NUE & NRE \\
\hline & \multicolumn{8}{|c|}{$P$ value } \\
\hline Tillage & 0.008 & 0.022 & 0.503 & 0.033 & 0.593 & 0.183 & 0.788 & 0.358 \\
\hline $\mathrm{N}$ source & 0.010 & 0.007 & 0.807 & 0.007 & 0.755 & 0.557 & 0.680 & 0.761 \\
\hline \multirow[t]{3}{*}{ Tillage $\times N$ source } & 0.236 & 0.146 & 0.871 & 0.185 & 0.621 & 0.529 & 0.637 & 0.638 \\
\hline & \multicolumn{8}{|c|}{ Treatment means } \\
\hline & \multicolumn{2}{|c|}{$\mathrm{kg} \mathrm{ha}^{-1}$} & $\mathrm{~kg} \mathrm{~kg}^{-1}$ & $\%$ & \multicolumn{2}{|c|}{$\mathrm{kg} \mathrm{ha}^{-1}$} & $\mathrm{~kg} \mathrm{~kg}^{-1}$ & $\%$ \\
\hline NT & 171.5abł & $123.8 a$ & 39.5 & $55.8 \mathrm{ab}$ & 261.3 & 133.4 & 37.1 & 85.5 \\
\hline ST & $188.4 a$ & $136.2 a$ & 35.1 & $58.5 a$ & 263.9 & 129.9 & 36.7 & 90.2 \\
\hline$C P$ & $144.2 c$ & $104.5 b$ & 37.2 & $45.2 c$ & 275.0 & 141.9 & 38.5 & 96.8 \\
\hline MP & $160.0 \mathrm{bc}$ & $121.7 \mathrm{ab}$ & 37.9 & $47.9 \mathrm{bc}$ & 276.6 & 141.7 & 37.0 & 89.3 \\
\hline UAN & $177.3 a$ & $131.4 a$ & 37.7 & $56.9 a$ & 267.7 & 135.4 & 37.6 & 89.8 \\
\hline UAN+nitrapyrin & $154.7 \mathrm{~b}$ & $111.7 \mathrm{~b}$ & 37.2 & $46.8 b$ & 270.7 & 138.1 & 37.1 & 91.1 \\
\hline
\end{tabular}

† NT, no till; ST, strip till; CP, chisel plow; MP, moldboard plow; UAN, urea ammonium nitrate.

¥ Within tillage and $\mathrm{N}$ source, columns that are followed by the same letters are not significantly different.

Table 2. Mixed model analysis showing probability of significant tillage and $\mathrm{N}$ source effects on daily $\mathrm{N}_{2} \mathrm{O}$ emissions in 2014,2015 , and 2016 , and across growing seasons near West Lafayette, IN.

\begin{tabular}{|c|c|c|c|c|c|c|c|c|c|c|}
\hline \multirow{2}{*}{ Treatment } & \multicolumn{10}{|c|}{ Year } \\
\hline & \multicolumn{4}{|c|}{2014} & 2015 & & \multicolumn{2}{|c|}{2016} & & 2014-2016 \\
\hline & \multicolumn{10}{|c|}{ Daily $\mathrm{N}_{2} \mathrm{O}$ emission } \\
\hline & & & 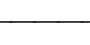 & 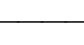 & $-\mathrm{g} N$ & $d^{-1}$ & & & 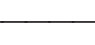 & + \\
\hline \multicolumn{11}{|l|}{ Tillaget } \\
\hline NT & \multicolumn{4}{|c|}{$37.64 c \neq$} & 39.86 & & \multicolumn{2}{|c|}{$31.46 a b$} & & 35.81 \\
\hline ST & \multicolumn{4}{|c|}{$41.67 \mathrm{~b}$} & 40.57 & & \multicolumn{2}{|c|}{$27.73 b$} & & 35.96 \\
\hline $\mathrm{CP}$ & \multicolumn{4}{|c|}{$40.18 \mathrm{bc}$} & 37.22 & & \multicolumn{2}{|c|}{$34.67 a$} & & 37.27 \\
\hline \multirow[t]{2}{*}{ MP } & \multicolumn{4}{|c|}{$47.02 \mathrm{a}$} & 39.01 & & \multicolumn{3}{|c|}{$31.50 \mathrm{ab}$} & 38.90 \\
\hline & NT & ST & $\mathrm{CP}$ & MP & & NT & ST & $\mathrm{CP}$ & MP & \\
\hline \multicolumn{11}{|l|}{ N source§ } \\
\hline UAN & $40.31 a$ & 39.83 & 39.59 & 47.02 & 38.13 & 31.17 & $30.54 a$ & 39.19 & $36.87 a$ & 37.96 \\
\hline \multirow[t]{2}{*}{ UAN+NP } & $34.97 \mathrm{~b}$ & 43.51 & 40.78 & 47.02 & 40.13 & 31.74 & $24.91 b$ & 30.15 & $26.12 b$ & 36.01 \\
\hline & \multicolumn{10}{|c|}{ Probability level } \\
\hline \multicolumn{11}{|l|}{$F$-test } \\
\hline $\mathrm{D} / \mathrm{Y}$ & \multicolumn{4}{|c|}{0.001} & 0.001 & & \multicolumn{2}{|c|}{0.001} & & 0.001 \\
\hline$T$ & \multicolumn{4}{|c|}{0.001} & 0.447 & & \multicolumn{2}{|c|}{0.014} & & 0.421 \\
\hline $\mathrm{N}$ & \multicolumn{4}{|c|}{0.918} & 0.190 & & \multicolumn{2}{|c|}{0.001} & & 0.187 \\
\hline $\mathrm{D} / \mathrm{Y} \times \mathrm{T}$ & \multicolumn{4}{|c|}{0.001} & 0.015 & & \multicolumn{2}{|c|}{0.008} & & 0.137 \\
\hline $\mathrm{D} / \mathrm{Y} \times \mathrm{N}$ & \multicolumn{4}{|c|}{0.318} & 0.807 & & \multicolumn{2}{|c|}{0.002} & & 0.063 \\
\hline $\mathrm{T} \times \mathrm{N}$ & \multicolumn{4}{|c|}{0.041} & 0.076 & & \multicolumn{2}{|c|}{0.031} & & 0.738 \\
\hline $\mathrm{D} / \mathrm{Y} \times \mathrm{T} \times \mathrm{N}$ & \multicolumn{4}{|c|}{0.554} & 0.994 & & \multicolumn{2}{|c|}{0.986} & & 0.482 \\
\hline
\end{tabular}

† NT, no-till; ST, strip-till; CP, chisel plow; MP, moldboard plow.

\# Within year, tillage, and $\mathrm{N}$ source, treatments that are followed by the same letters are not significantly different.

$\S$ UAN, urea ammonium nitrate; NP, nitrapyrin.

I T, tillage; D/Y, day/year of measurement; NP, nitrapyrin. 

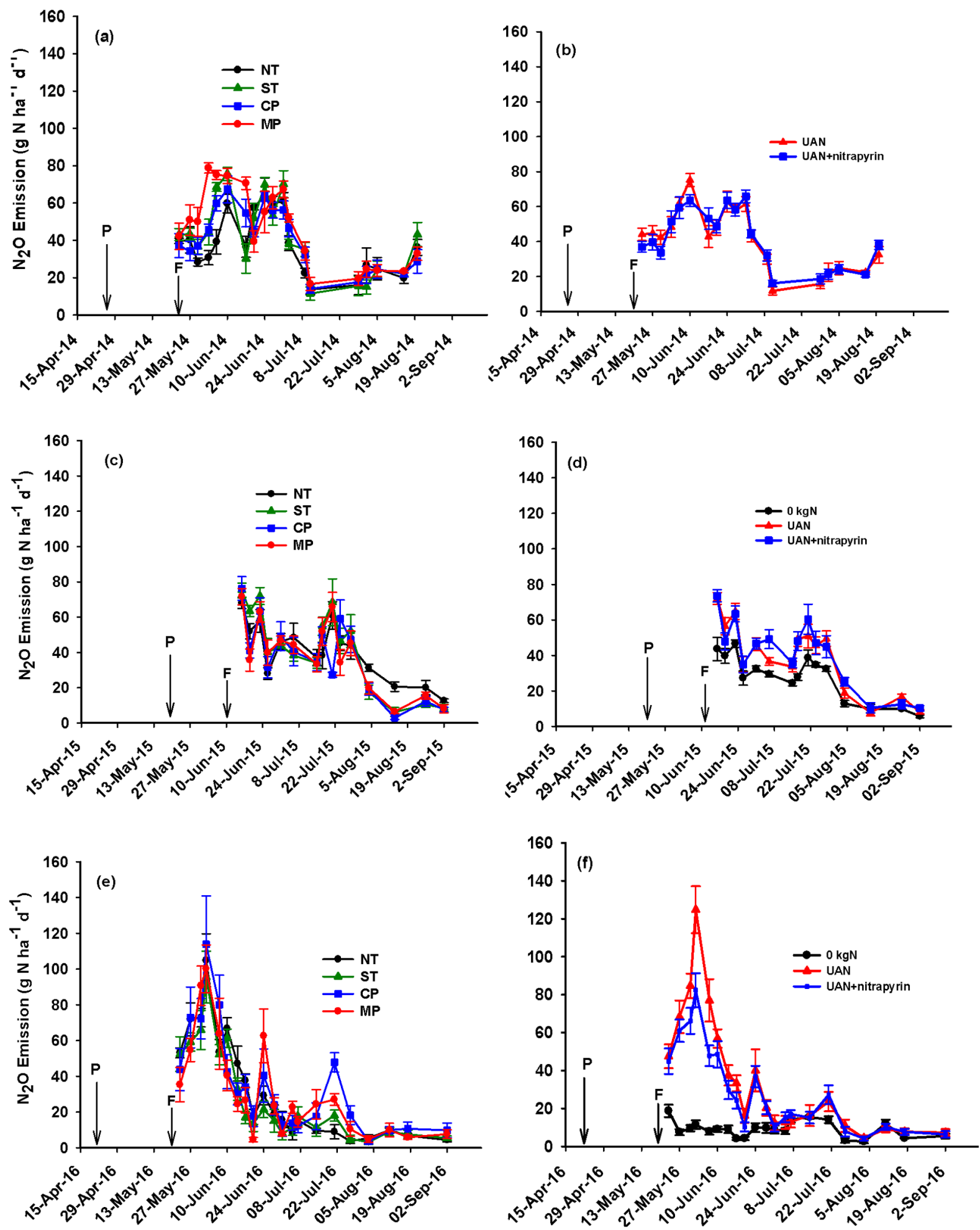

Fig. 1. Daily $\mathrm{N}_{2} \mathrm{O}$ emission as influenced by tillage (no till [NT], strip till [ST], chisel [CP], and moldboard [MP]) and $\mathrm{N}$ source (urea ammonium nitrate [UAN] with and without nitrapyrin) in 2014 to 2016 near West Lafayette, IN. $\mathrm{P}=$ corn planting date, $\mathrm{F}=\mathrm{N}$ application date.

declined rapidly to baseline levels by 2 August. Overall, average daily $\mathrm{N}_{2} \mathrm{O}$ emission for 2016 (Table 2) was significantly greater for CP $\left(34.6 \mathrm{~g} \mathrm{~N} \mathrm{ha}^{-1} \mathrm{~d}^{-1}\right)$ than for ST $\left(27.7 \mathrm{~g} \mathrm{~N} \mathrm{ha}^{-1} \mathrm{~d}^{-1}\right)$. Similarly, average daily $\mathrm{N}_{2} \mathrm{O}$ emission was $22 \%$ lower for $\mathrm{UAN}+$ nitrapyrin $\left(28.2 \mathrm{~g} \mathrm{~N} \mathrm{ha}^{-1} \mathrm{~d}^{-1}\right)$ than for UAN alone $\left(34.4 \mathrm{~g} \mathrm{~N} \mathrm{ha}^{-1} \mathrm{~d}^{-1}\right)$.

Cumulative seasonal $\mathrm{N}_{2} \mathrm{O}\left(\Sigma_{\mathrm{GS}} \mathrm{N}_{2} \mathrm{O}\right), \mathrm{N}_{2} \mathrm{O}_{\mathrm{Gr}}$ and FIEF due to tillage and $\mathrm{N}$ source calculated by year, and averaged across years, are presented in Table 3 and Supplemental Table S3, respectively. Cumulative $\mathrm{N}_{2} \mathrm{O}$ was affected by tillage in 2014, but not in 2015 and 2016 (Table 3). In 2014, $\Sigma_{G S} \mathrm{~N}_{2} \mathrm{O}$ for MP was $21 \%$ greater than for NT and $14 \%$ greater than for CP. Similarly, FIEF for 2015 was greater under NT $(0.45 \%)$ than under CP (0.27\%), but this was reversed for 2016, when FIEF was greatest with CP $(0.91 \%)$ and smallest with ST $(0.54 \%)$. Overall, FIEF was generally less than the $1 \%$ value reported by the Intergovernmental Panel on Climate Change, regardless of 
treatment or year of application. In contrast, $\mathrm{N}_{2} \mathrm{O}_{\mathrm{GY}}$ was similar among tillage and $\mathrm{N}$ source treatments in all $3 \mathrm{yr}$ of application. Averaged across treatments, $\Sigma_{\mathrm{GS}} \mathrm{N}_{2} \mathrm{O}$ for 2014 was $21 \%$ greater than 2015 and 2016, and $\mathrm{N}_{2} \mathrm{O}_{\mathrm{GY}}$ for 2014 was $12 \%$ greater than for 2016 (Supplemental Table S3). The FIEF for 2016 (0.77\%) was more than double that for 2015. Across years, $\Sigma_{\mathrm{GS}} \mathrm{N}_{2} \mathrm{O}$, $\mathrm{N}_{2} \mathrm{O}_{G Y}$, and FIEF were not significantly different among tillage and $\mathrm{N}$ source treatments (Supplemental Table S3).

\section{Relationship between Nitrous 0 xide and Nitrogen Uptake, and Use Efficiency}

The direction and strength of the relationships between $\mathrm{N}_{2} \mathrm{O}$ and TNU, NUE, and NRE varied by tillage, and N source. With zero $\mathrm{N}$ application, a significant $(P=0.015)$, relatively strong $\left(r^{2}\right.$ $=0.65)$, and negative linear relationship existed between $\mathrm{N}_{2} \mathrm{O}$ and TNU such that $\mathrm{N}_{2} \mathrm{O}$ decreased by $39 \mathrm{~g} \mathrm{~N}$ for every kilogram per hectare increase of TNU (Supplemental Fig. S1). In contrast, $\mathrm{N}$ source (UAN alone vs. UAN+nitrapyrin) had no measurable influence on the relationships between $\mathrm{N}_{2} \mathrm{O}$ and TNU, NRE, and NUE, as these relationships were weak $\left(r^{2}<0.05\right)$ and statistically not significant $(P=0.090-0.313)$. Here, we note that the relationship between $\mathrm{N}_{2} \mathrm{O}$ and TNU was significantly weakened with the addition of $220 \mathrm{~kg} \mathrm{~N}$ (with and without nitrapyrin); the slope of the regression was dramatically reduced from $0.039(39 \mathrm{~g}$ $\left.\mathrm{N} \mathrm{ha}^{-1}\right)$ with zero $\mathrm{N}$ to $0.003\left(3 \mathrm{~g} \mathrm{~N} \mathrm{ha}^{-1}\right)$ for $\mathrm{UAN}+$ nitrapyrin (Supplemental Fig. S1).

Tillage affected the relationships between $\mathrm{N}_{2} \mathrm{O}$ and TNU, NRE, and NUE more than N source (Table 4). A notable $\left(r^{2}=\right.$ $0.32)$ but nonsignificant $(P=0.053)$ linear relationship between $\mathrm{N}_{2} \mathrm{O}$ and TNU was only evident under NT, whereby $\mathrm{N}_{2} \mathrm{O}$ decreased by $4 \mathrm{~g} \mathrm{~N} \mathrm{ha}^{-1}$ for every kilogram increase of TNU. Similarly, significant and moderately strong negative linear relationships existed between $\mathrm{N}_{2} \mathrm{O}$ and NRE under NT and ST systems (NT: $P=0.02, r^{2}=0.43$; ST: $P=0.038, r^{2}=0.36$ ). However, a slope equality test showed that the regression slopes for these relationships under NT and ST were not significantly different (Table 4). Overall, the models showed that $\mathrm{N}_{2} \mathrm{O}$ decreased by $13 \mathrm{~g}$ $\mathrm{N} \mathrm{ha}^{-1}$ for every $1 \%$ increase of NRE under NT, and by $17 \mathrm{~g} \mathrm{Nha}^{-1}$ for every $1 \%$ increase of NRE under ST. Similarly, $\mathrm{N}_{2} \mathrm{O}$ decreased by $63 \mathrm{~g} \mathrm{~N}$ for every kilogram per kilogram gain of NUE when tillage was ST. However, we note that the relationships between $\mathrm{N}_{2} \mathrm{O}$ and $\mathrm{N}$ uptake and use efficiencies under $\mathrm{CP}$ were confounded, weak $\left(r^{2}=0-0.16\right)$, and positive linear (Table 4).

\section{Discussion}

\section{Grain Yield, Nitrogen Uptake, and Use Efficiency}

The average GY, N uptake, and NUE values reported in this experiment were similar to those previously reported for this location when $\mathrm{N}$ was applied at 180 to $220 \mathrm{~kg} \mathrm{~N} \mathrm{ha}^{-1}$ as anhydrous ammonia (Kovács et al., 2014) and UAN (Burzaco et al., 2014). Greater GY for 2014 and 2016, and higher NRE for 2016 than for 2015, were due to the combination of early planting and more favorable weather conditions, especially the quantity and distribution of precipitation in July and August of 2014 and 2016 (Supplemental Fig. S2). Precipitation in June 2015 shortly after N application was rather excessive (40\% greater than in June 2016, $48 \%$ greater than the $30-y r$ average) and probably resulted in $\mathrm{N}$ loss and lower GY and NRE in 2015. However, greater GY for MP relative especially to NT was probably because MP provided more favorable soil physical and chemical conditions that included lower bulk density, higher soil temperature, and organic matter mineralization (Gentry et al., 2013) and, consequently, a better and earlier corn plant establishment. The variable effects of nitrapyrin on GY were consistent with results from previous studies that examined the effects of fall- or spring-sidedressed nitrapyrin and enhanced efficiency fertilizers on corn yield. In this study, sidedressed UAN+nitrapyrin depressed GY in 2014 but had no effect in 2015 and 2016, and thus supported earlier reports where nitrapyrin was applied in the fall, spring, and split applied (Touchton et al., 1979; Randall et al., 2003; Burzaco et al., 2013, 2014). Similar inconsistent effects of enhanced efficiency fertilizers (e.g., ESN) on GY have also been widely reported (Dell et al., 2014; Halvorson and Bartolo, 2014; Sistani et al., 2014).

Overall, our average NRE value of $70 \%$ was higher than the 41 to $59 \%$ previously reported for this location for sidedress $\mathrm{N}$ applications (Burzaco et al., 2014; Kovács et al., 2015), and the

Table 3. Generalized linear model analysis showing probability of significant tillage and $\mathrm{N}$ source effects on cumulative seasonal $\left(\Sigma_{\mathrm{GS}} \mathrm{N}_{2} \mathrm{O}\right)$ and yieldscaled $\left(\mathrm{N}_{2} \mathrm{O}_{\mathrm{GY}}\right) \mathrm{N}_{2} \mathrm{O}$ emissions, and fertilizer-induced emission factor (FIEF) in 2014, 2015, and 2016 cropping seasons near West Lafayette, IN.

\begin{tabular}{|c|c|c|c|c|c|c|c|c|c|}
\hline \multirow{2}{*}{ Treatment $†$} & \multicolumn{3}{|c|}{2014} & \multicolumn{3}{|c|}{2015} & \multicolumn{3}{|c|}{2016} \\
\hline & $\Sigma_{G S} N_{2} \mathrm{O}$ & $\mathrm{N}_{2} \mathrm{O}_{\mathrm{GY}}$ & FIEF & $\Sigma_{\mathrm{GS}} \mathrm{N}_{2} \mathrm{O}$ & $\mathrm{N}_{2} \mathrm{O}_{\mathrm{GY}}$ & FIEF & $\Sigma_{G S} N_{2} \mathrm{O}$ & $\mathrm{N}_{2} \mathrm{O}_{\mathrm{GY}}$ & FIEF \\
\hline & \multicolumn{9}{|c|}{$P$ value } \\
\hline Tillage & 0.025 & 0.5971 & - & 0.401 & 0.558 & 0.215 & 0.333 & 0.510 & 0.191 \\
\hline N source & 0.986 & 0.420 & - & 0.497 & 0.514 & 0.343 & 0.119 & 0.161 & 0.103 \\
\hline \multirow[t]{3}{*}{ Tillage $\times N$ source } & 0.443 & 0.6109 & - & 0.674 & 0.599 & 0.398 & 0.706 & 0.618 & 0.674 \\
\hline & \multicolumn{9}{|c|}{ Treatment means } \\
\hline & $\mathrm{kg} \mathrm{N} \mathrm{ha}^{-1}$ & $\mathrm{~g} \mathrm{~N} \mathrm{Mg}^{-1}$ & $\%$ & $\mathrm{~kg} \mathrm{~N} \mathrm{ha}^{-1}$ & $\mathrm{~g} \mathrm{~N} \mathrm{Mg}^{-1}$ & $\%$ & $\mathrm{~kg} \mathrm{~N} \mathrm{ha}^{-1}$ & $\mathrm{~g} \mathrm{~N} \mathrm{Mg}^{-1}$ & $\%$ \\
\hline NT & $3.01 b \neq$ & 214.0 & ND§ & 2.91 & 244.83 & $0.45 a$ & 2.52 & 193.50 & $0.84 a b$ \\
\hline ST & 3.33ab & 231.3 & ND & 2.69 & 203.50 & $0.37 a b$ & 2.27 & 175.33 & $0.54 b$ \\
\hline $\mathrm{CP}$ & $3.28 b$ & 222.6 & ND & 2.46 & 221.67 & $0.27 b$ & 3.01 & 223.67 & $0.91 a$ \\
\hline MP & $3.82 \mathrm{a}$ & 238.6 & ND & 2.60 & 214.33 & $0.32 \mathrm{ab}$ & 2.66 & 198.17 & $0.78 a b$ \\
\hline UAN & $3.36 a$ & 221.2 & ND & 2.60 & 214.17 & 0.32 & 2.84 & 214.00 & 0.87 \\
\hline UAN+NP & $3.36 a$ & 232.2 & ND & 2.73 & 228.00 & 0.38 & 2.38 & 181.33 & 0.67 \\
\hline
\end{tabular}

† NT, no till; ST, strip till; CP, chisel plow; MP, moldboard plow; UAN, urea ammonium nitrate; NP, nitrapyrin.

$\neq$ Within tillage and $\mathrm{N}$ source, rows followed by the same letters are not significantly different.

$\S \mathrm{ND}$, not determined. 
Table 4. Linear regression model parameters for the relationships between $\mathrm{N}_{2} \mathrm{O}$ emission and total $\mathrm{N}$ uptake (TNU), recovery (NRE), and use efficiency (NUE) under tillage systems.

\begin{tabular}{|c|c|c|c|c|}
\hline \multirow{2}{*}{ Tillaget } & \multirow{2}{*}{$n$} & \multicolumn{3}{|c|}{ Regression parameters } \\
\hline & & Model & $R^{2}$ & $P>F$ \\
\hline & \multicolumn{4}{|c|}{ TNU } \\
\hline NT & 12 & $y=3.68-0.004 x$ & 0.32 & 0.053 \\
\hline ST & 12 & $y=3.95-0.006 x$ & 0.32 & 0.056 \\
\hline $\mathrm{CP}$ & 12 & $y=2.27+0.001 x$ & 0.06 & 0.456 \\
\hline \multirow[t]{2}{*}{ MP } & 12 & $y=3.023-0.002 x$ & 0.04 & 0.547 \\
\hline & \multicolumn{4}{|c|}{ NRE } \\
\hline NT & 12 & $y=3.72-0.013 x$ & 0.43 & 0.020 \\
\hline ST & 12 & $y=3.75-0.017 x$ & 0.36 & 0.038 \\
\hline $\mathrm{CP}$ & 12 & $y=2.36+0.002 x$ & 0.03 & 0.605 \\
\hline \multirow[t]{2}{*}{ MP } & 12 & $y=3.05-0.006 x$ & 0.05 & 0.469 \\
\hline & \multicolumn{4}{|c|}{ NUE } \\
\hline NT & 12 & $y=4.60-0.048 x$ & 0.19 & 0.160 \\
\hline ST & 12 & $y=4.77-0.063 x$ & 0.33 & 0.050 \\
\hline $\mathrm{CP}$ & 12 & $y=2.00+0.013 x$ & 0.04 & 0.532 \\
\hline \multirow[t]{3}{*}{ MP } & 12 & $y=4.53-0.050 x$ & 0.28 & 0.075 \\
\hline & \multicolumn{4}{|c|}{ Test for equality of slopes $\neq$} \\
\hline & df & Contrast sum of squares & $F$ value & $\operatorname{Pr}>F$ \\
\hline NRE (NT vs. ST) & 1 & 0.026 & 0.20 & 0.663 \\
\hline
\end{tabular}

† NT, no till; ST, strip till; CP, chisel plow; MP, moldboard plow.

$\neq$ Test for equality of regression slopes presented is for treatments where the relationship between $\mathrm{N}_{2} \mathrm{O}$ emission and NRE was significant at $P$ $=0.05$.

$55 \%$ average reported from across North America corn systems for $\mathrm{N}$ rates $>150 \mathrm{~kg} \mathrm{~N} \mathrm{ha}^{-1}$ (Omonode et al., 2017) in studies that measured both NRE and $\Sigma_{G S} \mathrm{~N}_{2} \mathrm{O}$. Our NRE was twofold higher than the 31 to $37 \%$ reported for north-central US locations (Cassman et al., 2002; Al-Kaisi and Kwaw-Mensah, 2007; Rubin et al., 2016). However, the average NUE value of $37 \mathrm{~kg}$ $\mathrm{kg}^{-1}$ was similar to the values previously reported for this location (Burzaco et al., 2014; Kovács et al., 2015), and thus indicated that coapplication of UAN and nitrapyrin and long-term tillage management did not influence the amount of grain produced from an equivalent amount of $\mathrm{N}$ applied in this environment.

\section{Nitrous 0xide Emission}

Variability in daily $\mathrm{N}_{2} \mathrm{O}$ emission with tillage and year reflected the significant sampling date, date $\times$ tillage, and date $\times$ $\mathrm{N}$ source effects due to the differences of weather and soil conditions at the time of measurements. The $\mathrm{N}_{2} \mathrm{O}$ emission peaks that occurred around 10 and 24 June 2014 were attributed to the collective impacts of 14 to $22 \mathrm{~mm}$ of precipitation events on 9 , 11 , and 19 June, soil temperatures of 19 to $25^{\circ} \mathrm{C}$, and volumetric water content (VWC) that increased from $27 \mathrm{~m}^{3} \mathrm{~m}^{-3}$ on 2 June to $51 \mathrm{~m}^{3} \mathrm{~m}^{-3}$ on 10 June, and from $25 \mathrm{~m}^{3} \mathrm{~m}^{-3}$ on 17 June to $60 \mathrm{~m}^{3} \mathrm{~m}^{-3}$ on 23 June. The peaks of 23 June and 22 July 2015 were also the result of the 26- and 46-mm precipitation events that occurred on 22 June and 18 July, which increased VWC that was already $>44 \mathrm{~m}^{3} \mathrm{~m}^{-3}$, and soil temperature that averaged $23^{\circ} \mathrm{C}$. Similarly, the high $\mathrm{N}_{2} \mathrm{O}$ peak of 2 June 2016 resulted from the dramatic increase in VWC after 7 to $14 \mathrm{~d}$ of little or no precipitation when soil temperature averaged $23^{\circ} \mathrm{C}$. In general, the significant tillage effects that resulted in greater mean daily $\mathrm{N}_{2} \mathrm{O}$ for MP than for NT, ST, and CP in 2014, and for CP relative to $S T$ in 2016, were attributed to treatment differences of soil temperature and VWC. In 2014, soil temperature and VWC accounted for 11 of $22 \%$ of the total variability associated with $\mathrm{N}_{2} \mathrm{O}$ emissions, and for 11 of $17 \%$ total variability of $\mathrm{N}_{2} \mathrm{O}$ emission in 2016 (data not shown).

Overall, $\Sigma_{G S} \mathrm{~N}_{2} \mathrm{O}$ for 2014 was $21 \%$ higher than for 2015 and 2016 (average $=2.64 \mathrm{~kg} \mathrm{~N} \mathrm{ha}^{-1}$ ), perhaps due to the combined effects of weather and the amount of the applied $\mathrm{N}$ that was available for denitrification in the first $30 \mathrm{~d}$ after $\mathrm{N}$ application. Large precipitation events in June and July of 2015 and 2016 shortly after $\mathrm{N}$ application (Supplemental Fig. S2, insert) probably resulted in significant $\mathrm{N}$ leaching losses, smaller amounts of $\mathrm{N}$ available for denitrification, and, consequently, lower seasonal $\mathrm{N}_{2} \mathrm{O}$ emissions. Although tillage effects on $\Sigma_{\mathrm{GS}} \mathrm{N}_{2} \mathrm{O}$ were significant only in one of $3 \mathrm{yr}, \Sigma_{\mathrm{GS}} \mathrm{N}_{2} \mathrm{O}$ loss was generally in the order $\mathrm{MP}>\mathrm{CP}>\mathrm{ST}>\mathrm{NT}$, thus affirming our earlier observations from these and other tillage plots in this location (Omonode et al., 2011., 2015). The pattern of $\mathrm{N}_{2} \mathrm{O}$ loss also supported findings from several other field research studies that found greater $\mathrm{N}_{2} \mathrm{O}$ emitted from tilled compared with NT or reduced-tillage systems (Jacinthe and Dick, 1997; Kessavalou et al., 1998).

The variable effect of nitrapyrin on $\mathrm{N}_{2} \mathrm{O}$ emission (significant effect on daily $\mathrm{N}_{2} \mathrm{O}$ under NT in 2014 and under ST and MP in 2016, but no effect on cumulative $\mathrm{N}_{2} \mathrm{O}$ ) was not entirely unexpected, as contrasting effects of nitrapyrin on $\mathrm{N}_{2} \mathrm{O}$ emissions have been reported more frequently in the literature (Parkin and Hatfield, 2010; Omonode and Vyn, 2013; Burzaco et al., 2013). Thus, although nitrapyrin has the potential to delay the nitrification of ammoniacal fertilizers (Omonode and Vyn, 2013), its potential to actually reduce $\mathrm{N}_{2} \mathrm{O}$ emission across the growing season is limited because nitrapyrin's effects on interrupting the conversion of $\mathrm{NH}_{4}^{+}$to $\mathrm{NO}_{2}^{-}$in soil are short-lived (Parkin and Hatfield, 2010) and appear to be dependent on the tillage system applied. Delayed nitrification is also not helpful in substantially reducing $\mathrm{N}_{2} \mathrm{O}$ emissions if there is no gain in synchrony in the timing of availability of $\mathrm{N}$ released by nitrification and plant $\mathrm{N}$ uptake, and available $\mathrm{N}$ is not taken up by corn plants before being denitrified. Overall, this study generally indicated that nitrapyrin was unlikely to improve corn NRE and reduce $\mathrm{N}_{2} \mathrm{O}$ emissions at higher rates of in-season $\mathrm{N}$ application, such as those applied in this experiment. For this location, Burzaco et al. (2013) reported that nitrapyrin addition significantly reduced $\mathrm{N}_{2} \mathrm{O}$ loss from UAN when $\mathrm{N}$ was applied at a rate of $90 \mathrm{~kg}$ $\mathrm{N} \mathrm{ha}^{-1}$, but not at $180 \mathrm{~kg} \mathrm{~N} \mathrm{ha}^{-1}$.

\section{Relationship between Nitrous 0xide and Nitrogen Uptake, and Use Efficiency}

Relatively little research has been conducted to quantify the relationships between $\mathrm{N}_{2} \mathrm{O}$ and $\mathrm{N}$ uptake, NRE, or NUE (Van Groenigen et al., 2010; Venterea et al., 2016; Omonode et al., 2017), and even less research has examined these relationships in long-term tillage systems. Thus, it was difficult to compare our results with the existing literature. Nevertheless, the significant and negative linear relationship between $\mathrm{N}_{2} \mathrm{O}$ and TNU and NRE under NT and ST supported the long-postulated hypothesis that an increase of $\mathrm{N}$ uptake or NRE in corn will reduce $\mathrm{N}_{2} \mathrm{O}$ emission. These findings were also similar to those reported by Van Groenigen et al. (2010) in a meta-analysis that aggregated NRE across different crop species, and by Omonode et al. (2017) in analyses that used data aggregated over North America's corn 
cropping systems. The dramatic reduction of regression parameter values for the relationship between $\mathrm{N}_{2} \mathrm{O}$ and TNU due to addition of $220 \mathrm{~kg} \mathrm{~N}$ was similar to reports by Omonode et al. (2017) and was attributed to simultaneous increase of plant $\mathrm{N}$ uptake and $\mathrm{N}_{2} \mathrm{O}$ emissions as $\mathrm{N}$ rate was increased up to and beyond the crop requirement.

Overall, the moderately strong and significant relationship of $\mathrm{N}_{2} \mathrm{O}$ emission with NRE for NT and ST was attributed to the combination of low synchrony between the peak periods of $\mathrm{N}_{2} \mathrm{O}$ emission (<24 DAP in this study) and the recovery of applied $\mathrm{N}$ by the plant, and to the fact that $\mathrm{N}_{2} \mathrm{O}$ was the only source of $\mathrm{N}$ loss considered in the models. Halvorson and Del Grosso (2012) and Omonode et al. (2011) showed that $\sim 50$ to $80 \%$ of seasonal cumulative $\mathrm{N}_{2} \mathrm{O}$ emissions occur in 30 to 40 DAP, when the corn plant was in its early growth stages (e.g., V5-V7) and plant $\mathrm{N}$ uptake was relatively small; in this study, $\sim 56$ to $66 \%$ of seasonal $\mathrm{N}_{2} \mathrm{O}$ emission occurred in $\leq 30$ DAP. Several studies also found that $\mathrm{N}_{2} \mathrm{O}$ accounted for only a small fraction of the total $\mathrm{N}$ lost from the system after $\mathrm{N}$ application; most $\mathrm{N}$ losses occurred as $\mathrm{NH}_{3}$ volatilization and/or $\mathrm{NO}_{3}{ }^{-}$leaching, which, respectively, accounted for $\sim 10$ and $30 \%$ of applied $\mathrm{N}$ compared with $\sim 3 \%$ for $\mathrm{N}_{2} \mathrm{O}$ losses (Mosier et al., 1998; De Klein et al., 2006; Venterea et al., 2012). Nevertheless, because our average NRE levels were high, it is possible that those other reactive $\mathrm{N}$ losses (as a fraction of applied $\mathrm{N}$ ) were considerably lower in our experiments.

\section{Conclusion}

Our results confirmed that relatively strong functional relationships existed between seasonal $\mathrm{N}_{2} \mathrm{O}$ emissions and $\mathrm{N}$ recovery efficiency; cumulative seasonal $\mathrm{N}_{2} \mathrm{O}$ loss abated as corn NRE or NUE were improved under NT and ST when N was sidedressed at the recommended rate. However, the $\mathrm{N}_{2} \mathrm{O}$ abatement rate was greater under ST than under NT. The analysis showed that NT or a reduction in tillage intensity, as in ST, has the potential to maintain yield, improve NRE, and reduce seasonal $\mathrm{N}_{2} \mathrm{O}$ emissions. More research is needed where $\mathrm{N}_{2} \mathrm{O}$ emissions and NRE are simultaneously measured to better understand and model the functional relationships between $\mathrm{N}_{2} \mathrm{O}$ and NRE in the weeks after banded $\mathrm{N}$ applications to corn.

\section{Acknowledgments}

This study was conducted with the financial support (Project Grant IPNI-2015-USA-4RN28) from the 4R Research Fund established in 2013 within the Foundation for Agronomic Research (FAR) with the goal of providing scientific guidance for improved agricultural nutrient stewardship across North America. The FAR is a nonprofit 501(c)(3) research and education foundation that is managed by the International Plant Nutrition Institute (IPNI). Further financial support came from USDA-Hatch Grant 1007764 and from USDA National Institute of Food and Agriculture (NIFA) Grant \#2013-68002-20421 to Purdue University. We also acknowledge the technical assistance of Cropping Systems Laboratory team members from 2014 to 2016, including the long-term tillage plot maintenance capably provided by Terry West since 1979.

\section{References}

Abendroth, L.J., R.W. Elmore, M.J. Boyer, and S.K. Marlay. 2011. Corn growth and development. PMR 1009. Iowa State Univ. Ext. Ames.

Al-Kaisi, M., and D. Kwaw-Mensah. 2007. Effect of tillage and nitrogen rate on corn yield and nitrogen and phosphorus uptake in a corn-soybean rotation. Agron. J. 99:1548-1558. doi:10.2134/agronj2007.0012
Breitenbeck, G.A., and J.M. Bremner. 1986a. Effects of rate and depth of fertilizer application on emission of nitrous oxide from soil fertilized with anhydrous ammonia. Biol. Fertil. Soils 2:201-204. doi:10.1007/BF00260844

Breitenbeck, G.A., and J.M. Bremner. 1986b. Effects of various nitrogen fertilizers on emission of nitrous oxide from soils. Biol. Fertil. Soils 2:195-199. doi: $10.1007 / B F 00260843$

Bremner, J.M. 1997. Sources of nitrous oxide in soils. Nutr. Cycling Agroecosyst. 49:7-16. doi:10.1023/A:1009798022569

Bremner, J.M., and A.M. Blackmer. 1978. Nitrous oxide emissions from soils during nitrification of fertilizer nitrogen. Science 199:295-296. doi:10.1126/ science.199.4326.295

Burzaco, J.P., I.A. Ciampitti, and T.J. Vyn. 2014. Nitrapyrin impacts on maize yield and nitrogen use efficiency with spring-applied nitrogen: Field studies vs. meta-analysis comparison. Agron. J. 106:753-760. doi:10.2134/ agronj2013.0043

Burzaco, J.P., D.R. Smith, and T.J. Vyn. 2013. Nitrous oxide emissions in Midwest US maize production vary widely with band-injected $\mathrm{N}$ fertilizer rates, timing and nitrapyrin presence. Environ. Res. Lett. 8:035031. doi:10.1088/1748-9326/8/3/035031

Cassman, K.G., A. Dobermann, and D.T. Walters. 2002. Agroecosystems, nitrogen-use efficiency, and nitrogen management. Ambio 31:132-140. doi: $10.1579 / 0044-7447-31.2 .132$

Ciampitti, I.A., and T.J. Vyn. 2011. A comprehensive study of plant density consequences on nitrogen uptake dynamics of maize plants from vegetative to reproductive stages. Field Crops Res. 121:2-18. doi:10.1016/j. fcr.2010.10.009

De Klein, C.R., S.A. Novoa, S. Ogle, K.A. Smith, P. Rochette, T.C. Wirth, et al. 2006. $\mathrm{N}_{2} \mathrm{O}$ emissions from managed soils, and $\mathrm{CO}_{2}$ emissions from lime and urea application. In: S. Eggleston, et al., editors, 2006 IPCC guidelines for national greenhouse gas inventories, Vol. 4: Agriculture, forestry and other land use. Intergov. Panel Clim. Change, Hayama, Japan. p. 11.1-11.54.

Dell, C.J., K. Han, R.B. Bryant, and J.P. Schmidt. 2014. Nitrous oxide emissions with enhanced efficiency nitrogen fertilizers in a rainfed system. Agron. J. 106:723-731. doi:10.2134/agronj2013.0108

Drury, C.F., W.D. Reynolds, X.M. Yang, N.B. McLaughlin, T.W. Welacky, W. Calder, et al. 2012. Nitrogen Source, Application time, and tillage effects on soil nitrous oxide emissions and corn grain yields. Soil Sci. Soc. Am. J. 76:1268-1279. doi:10.2136/sssaj2011.0249

Engel, R., D.L. Liang, R. Wallander, and A. Bembenek. 2010. Influence of urea fertilizer placement on nitrous oxide production from a silt loam soil. J. Environ. Qual. 39:115-125. doi:10.2134/jeq2009.0130

Fujinuma, R., R.T. Venterea, and C. Rosen. 2011. Broadcast urea reduces $\mathrm{N}_{2} \mathrm{O}$ but increases $\mathrm{NO}$ emissions compared with conventional and shallowapplied anhydrous ammonia in a coarse-textured soil. J. Environ. Qual. 40:1806-1815. doi:10.2134/jeq2011.0240

Gentry, L.F., M.L. Ruffo, and F.E. Below. 2013. Identifying factors controlling the continuous corn yield penalty. Agron. J. 105:295-303. doi:10.2134/ agronj2012.0246

Halvorson, A.D., and M.E. Bartolo. 2014. Nitrogen source and rate effects on irrigated corn yields and nitrogen-use efficiency. Agron. J. 106:681-693. doi:10.2134/agronj2013.0001

Halvorson, A.D., and S.J. Del Grosso. 2012. Nitrogen source and placement effects on soil nitrous oxide emissions from no-till corn. J. Environ. Qual. 41:1349-1360. doi:10.2134/jeq2012.0129

Halvorson, A.D., and S.J. Del Grosso. 2013. Nitrogen placement and source effects on nitrous oxide emissions and yields of irrigated corn. J. Environ. Qual. 42:312-322. doi:10.2134/jeq2012.0315

Halvorson, A.D., S.J. Del Grosso, and F. Alluvione. 2010a. Nitrogen source effects on nitrous oxide emissions from irrigated no-till Corn. J. Environ. Qual. 39:1554-1562. doi:10.2134/jeq2010.0041

Halvorson, A.D., S.J. Del Grosso, and F. Alluvione. 2010b. Tillage and inorganic nitrogen source effects on nitrous oxide emissions from irrigated cropping Systems. Soil Sci. Soc. Am. J. 74:436-445. doi:10.2136/sssaj2009.0072

Halvorson, A.D., S.J. Del Grosso, and C.P. Jantalia. 2011. Nitrogen source effects on soil nitrous oxide emissions from strip-till corn. J. Environ. Qual. 40:1775-1786. doi:10.2134/jeq2011.0194

Halvorson, A.D., S.J. Del Grosso, and C.A. Reule. 2008. Nitrogen, tillage, and crop rotation effects on nitrous oxide emissions from irrigated cropping systems. J. Environ. Qual. 37:1337-1344. doi:10.2134/jeq2007.0268

IPCC. 2014. Climate change 2014: Synthesis report. Contribution of Working Groups I, II and III to the Fifth Assessment Report of the Intergovernmental Panel on Climate Change. Intergov. Panel Clim. Change, Geneva, Switzerland.

Jacinthe, P.A., and W.A. Dick. 1997. Soil management and nitrous oxide emissions from cultivated fields in southern Ohio. Soil Tillage Res. 41:221235. doi:10.1016/S0167-1987(96)01094-X 
Kessavalou, A., A.R. Mosier, J.W. Doran, R.A. Drijber, D.J. Lyon, and O. Heinemeyer. 1998. Fluxes of carbon dioxide, nitrous oxide, and methane in grass sod and winter wheat-fallow tillage management. J. Environ. Qual. 27:1094-1104. doi:10.2134/jeq1998.00472425002700050015x

Klemedtsson, I., B.H. Svensson, and T. Rosswall. 1988. A method of selective inhibition to distinguish between nitrification and denitrification as sources of nitrous oxide in soil. Biol. Fertil. Soils 6:112-119. doi:10.1007/ BF00257659

Kovács, P., G.E. Van Scoyoc, T.A. Doerge, J.J. Camberato, and T.J. Vyn. 2014. Pre-plant anhydrous ammonia placement consequences on no-till versus conventional-till maize growth and nitrogen responses. Agron. J. 106:634644. doi:10.2134/agronj2013.0356

Kovács, P., G.E. Van Scoyoc, T.A. Doerge, J.J. Camberato, and T.J. Vyn. 2015. Anhydrous ammonia timing and rate effects on maize nitrogen use efficiencies. Agron. J. 107:1205-1214. doi:10.2134/agronj14.0350

Liu, X.J., A.R. Mosier, A.D. Halvorson, C.A. Reule, and F.S. Zhang. 2007. Dinitrogen and $\mathrm{N}_{2} \mathrm{O}$ emissions in arable soils: Effect of tillage, $\mathrm{N}$ source and soil moisture. Soil Biol. Biochem. 39:2362-2370. doi:10.1016/j. soilbio.2007.04.008

Liu, X.J., A.R. Mosier, A.D. Halvorson, and F.S. Zhang. 2005. Tillage and nitrogen application effects on nitrous and nitric oxide emissions from irrigated corn fields. Plant Soil 276:235-249. doi:10.1007/s11104-005-4894-4

Liu, X.J., A.R. Mosier, A.D. Halvorson, and F.S. Zhang. 2006. The impact of nitrogen placement and tillage on $\mathrm{NO}, \mathrm{N}_{2} \mathrm{O}, \mathrm{CH}_{4}$ and $\mathrm{CO}_{2}$ fluxes from a clay loam soil. Plant Soil 280:177-188. doi:10.1007/s11104-005-2950-8

McSwiney, C.P., and G.P. Robertson. 2005. Nonlinear response of $\mathrm{N}_{2} \mathrm{O}$ flux to incremental fertilizer addition in a continuous maize ( $Z_{\text {ea }}$ mays L.) cropping system. Glob. Change Biol. 11:1712-1719. doi: $10.1111 /$ j.1365-2486.2005.01040.x

Mosier, A., C. Kroeze, C. Nevison, O. Oenema, S. Seitzinger, and O. van Cleemput. 1998. Closing the global $\mathrm{N}_{2} \mathrm{O}$ budget: Nitrous oxide emissions through the agricultural nitrogen cycle. Nutr. Cycling Agroecosyst. 52:225-248. doi:10.1023/A:1009740530221

Mosier, A.R., A.D. Halvorson, C.A. Reule, and X.J. Liu. 2006. Net global warming potential and greenhouse gas intensity in irrigated cropping systems in northeastern Colorado. J. Environ. Qual. 35:1584-1598. doi:10.2134/ jeq2005.0232

Myhre, G., D. Shindell, F.M. Bréon, W. Collins, J. Fuglestvedt, J. Huang, et al. 2013. Anthropogenic and natural radiative forcing In: T.F. Stocker, et al., editors, Climate change 2013: The physical science basis. Contribution of Working Group I to the Fifth Assessment Report of the Intergovernmental Panel on Climate Change. Cambridge Univ. Press, Cambridge, UK, and New York.

Omonode, R.A., A.D. Halvorson, B. Gagnon, and T.J. Vyn. 2017. Achieving lower nitrogen balance and higher nitrogen recovery efficiency reduces nitrous oxide emissions in North America's maize cropping systems. Front. Plant Sci. 8:1080. doi:10.3389/fpls.2017.01080

Omonode, R.A., P. Kovács, and T.J. Vyn. 2015. Tillage and nitrogen rate effects on area- and yield-scaled nitrous oxide emissions from pre-plant anhydrous ammonia. Agron. J. 107:605-614. doi:10.2134/agronj14.0440

Omonode, R.A., D.R. Smith, A. Gál, and T.J. Vyn. 2011. Soil nitrous oxide emissions in corn following three decades of tillage and rotation treatments. Soil Sci. Soc. Am. J. 75:152-163. doi:10.2136/sssaj2009.0147

Omonode, R.A., and T.J. Vyn. 2013. Nitrification kinetics and nitrous oxide emissions when nitrapyrin is coapplied with urea-ammonium nitrate. Agron. J. 105:1475-1486. doi:10.2134/agronj2013.0184

Parkin, T.B., and J.L. Hatfield. 2010. Influence of nitrapyrin on $\mathrm{N}_{2} \mathrm{O}$ losses from soil receiving fall-applied anhydrous ammonia. Agric. Ecosyst. Environ. 136:81-86. doi:10.1016/j.agee.2009.11.014
Randall, G.W., and J.A. Vetsch. 2005. Corn production on a subsurface-drained mollisol as affected by fall versus spring application of nitrogen and nitrapyrin. Agron. J. 97:472-478. doi:10.2134/agronj2005.0472

Randall, G.W., J.A. Vetsch, and Je.R. Huffman. 2003. Corn production on a subsurface-drained mollisol as affected by time of nitrogen application and nitrapyrin. Agron. J. 95:1213-1219. doi:10.2134/agronj2003.1213

Ravishankara, A.R., J.S. Daniel, and R.W. Portmann. 2009. Nitrous oxide $\left(\mathrm{N}_{2} \mathrm{O}\right)$ : The dominant ozone-depleting substance emitted in the 21 st century. Science 326:123-125. doi:10.1126/science.1176985

Rubin, J.C., A.M. Struffert, F.G. Fernández, and J.A. Lamb. 2016. Maize yield and nitrogen use efficiency in upper Midwest irrigated sandy soils. Agron. J. 108:1681-1691. doi:10.2134/agronj2015.0552

SAS Institute. 2013. The SAS system for Windows. Version 9.3. SAS Inst., Cary, NC.

Sawyer, J.E., K.P. Woli, D.W. Barker, and J.L. Pantoja. 2017. Stover removal impact on corn plant biomass, nitrogen, and use efficiency. Agron. J. 109:802-810. doi:10.2134/agronj2016.11.0672

Sistani, K.R., M. Jn-Baptiste, and J.R. Simmons. 2014. Corn response to enhanced-efficiency nitrogen fertilizers and poultry litter. Agron. J. 106:761770. doi:10.2134/agronj2013.0087

Touchton, J.T., R.G. Hoeft, L.F. Welch, D.L. Mulvaney, M.G. Oldham, and F.E. Zajicek. 1979. N uptake and corn yield as affected by applications of nitrapyrin with anhydrous ammonia. Agron. J. 71:238-242. doi:10.2134/agro nj1979.00021962007100020006x

USDA-ERS. 2018. Fertilizer use and price. USDA Econ. Res. Serv., Washington, DC. https://www.ers.usda.gov/data-products/fertilizer-use-and-price. aspx (accessed 8 Dec. 2018).

Van Groenigen, J.W., G.L. Velthof, O. Oenema, K.J. Van Groenigen, and C. van Kessel. 2010. Towards an agronomic assessment of $\mathrm{N}_{2} \mathrm{O}$ emissions: A case study for arable crops. Eur. J. Soil Sci. 61:903-913. doi:10.1111/j.1365-2389.2009.01217.x

van Kessel, C., R. Venterea, J. Six, M.A. Adviento-Borbe, B. Linquist, and K.J. van Groenigen. 2013. Climate, duration, and $\mathrm{N}$ placement determine $\mathrm{N}_{2} \mathrm{O}$ emissions in reduced tillage systems: A meta-analysis. Glob. Change Biol. 19:33-44. doi:10.1111/j.1365-2486.2012.02779.x

Venterea, R.T., M. Bijesh, and M.S. Dolan. 2011. Fertilizer source and tillage effects on yield-scaled nitrous oxide emissions in a corn cropping system. J. Environ. Qual. 40:1521-1531. doi:10.2134/jeq2011.0039

Venterea, R.T., and J.A. Coulter. 2015. Split application of urea does not decrease and may increase nitrous oxide emissions in rainfed corn. Agron. J. 107:337-348. doi:10.2134/agronj14.0411

Venterea, R.T., J.A. Coulter, and M.S. Dolan. 2016. Evaluation of intensive "4R" strategies for decreasing nitrous oxide emissions and nitrogen surplus in rainfed corn. J. Environ. Qual. 45:1186-1195. doi:10.2134/jeq2016.01.0024

Venterea, R.T., M.S. Dolan, and T.E. Ochsner. 2010. Urea decreases nitrous oxide emissions compared with anhydrous ammonia in a Minnesota corn cropping system. Soil Sci. Soc. Am. J. 74:407-418. doi:10.2136/ sssaj2009.0078

Venterea, R.T., A.D. Halvorson, N.R. Kitchen, M.A. Liebig, M.A. Cavigelli, S.J. Del Grosso, et al. 2012. Challenges and opportunities for mitigating nitrous oxide emissions from fertilized cropping systems. Front. Ecol. Environ. 10:562-570. doi:10.1890/120062

Wang, Z., J. Gao, and B.L. Ma. 2014. Concurrent improvement in maize yield and nitrogen use efficiency with integrated agronomic management strategies. Agron. J. 106:1243. doi:10.2134/agronj13.0487 